\title{
EFEKTIVITAS TERAPI MASASE TERHADAP NYERI GERAK DAN FUNGSI GERAK SENDI ANKLE PASCA CEDERA ANKLE
}

\author{
Setiawan Jodi ${ }^{1}$, B.M Wara Kushartanti ${ }^{1}$ \\ ${ }^{1}$ Fakultas Ilmu Keolahragaan, Universitas Negeri Yogyakarta, Jl. Colombo No. 1, Karangmalang Depok, \\ Sleman, Yogyakarta, Indonesia \\ setiawan.jodi2015@student.uny.ac.id,bm_warakushartanti@uny.ac.id
}

\begin{abstract}
Abstrak
Salah satu ancaman cedera yang kerap kali membayangi seseorang dengan aktivitas fisik yang tinggi adalah cedera sendi ankle, cedera sendi ankle umumya merupakan gangguan pada bagian ligamen sendi yang diakibatkan oleh tarikan berlebih. Penelitian ini bertujuan untuk mengetahui efektivitas terapi masase terhadap nyeri gerak dan fungsi gerak sendi ankle pasca cedera ankle. Terapi masase yang digunakan dalam penelitian adalah soft tissue release dan deep tissue massage yang dilengkapi dengan reposisi gerak. Penelitian ini merupakan penelitian pre-experimental design dengan metode one-group pre-test - post-test design. Populasi sample penelitian ini adalah pasien Lab/Klinik Terapi Latihan FIK UNY yang selama tiga bulan (Februari - April 2019) diperkirakan sejumlah 100 orang. Teknik sampling data menggunakan insidental sampling dengan rumus Slovin (nilai kritis 20\%) sehingga diperoleh subjek sebanyak 20 orang. Instrumen yang digunakan berupa catatan medis hasil dari anamnesa dan pemeriksaan yang dibuat dengan memodifikasi Lower Extremity Functional Scale (Binkley et al, 1999) yang telah di uji validitas menggunakan Pearson correlation dan reliabilitas dengan Cronbach's Alpha. Nyeri gerak dan fungsi gerak sebelum dan sesudah perlakukan dianalisis dengan menggunakan uji beda dua kelompok berpasangan non- parametrik Wilcoxon Signed Ranks Test. Data pre dan post ini digunakan dalam uji efektivitas. Hasil penelitian menunjukan bahwa terapi masase yang meliputi pelemasan otot dengan soft tissue release dan deep tissue massage dan ditambah dengan reposisi gerak dapat mengurangi nyeri gerak dan meningkatkan fungsi gerak dari sendi ankle pasca cedera ankle $(\mathrm{p}<$ $0,05)$, dengan efektivitas penurunan nyeri gerak sebesar 70,31\% dan peningkatan fungsi gerak sebesar $20,62 \%$. Dapat disimpulkan bahwa perlakuan massage tersebut efektif dalam memperbaiki nyeri gerak dan fungsi ankle paska cedera.
\end{abstract}

Kata Kunci: terapi masase, soft tissue release, deep tissue massage, cedera ankle.

\section{EFFECTIVENESS OF MASSAGE THERAPY ON MOTION PAIN AND FUNCTION OF ANKLE JOINTS AFTER ANKLE INJURY}

\begin{abstract}
One of the threat of injury that often overshadows someone with high physical activity is ankle joint injury, ankle joint injury is generally a disruption in the ligament of the joint caused by excessive traction. This study aims to determine the effectiveness of massage therapy for motion pain and ankle joint function after ankle injury. Massage therapy used in this research is soft tissue release and deep tissue massage which is equipped with motion repositioning. This research is a pre-experimental design research with one-group pre-test - post-test design method. The population of this study sample is the patients of the Lab / Clinical Training Clinic of FIK UNY which for an estimated three months (February - April 2019) amounted to 100 people. Data sampling technique used incidental sampling with the Slovin formula (critical value of 20\%) to obtain as many as 20 subjects. The instrument used in the form of medical records from the history and examination made by modifying the Lower Extremity Functional Scale (Binkley et al, 1999) that has been tested for validity using Pearson correlation and reliability with Cronbach's Alpha. Motion pain and motion function before and after treatment were analyzed using a two-group non-parametric paired Wilcoxon Signed Ranks Test. This pre and post data is used in the effectiveness test. The results showed that massage therapy which includes muscle relaxation with
\end{abstract}


soft tissue release and deep tissue massage and coupled with motion repositioning can reduce motion pain and improve motion function of the ankle joint after ankle injury ( $p<0.05)$, with the effectiveness of decreasing motion pain by $70.31 \%$ and an increase in motion function by $20.62 \%$. It can be concluded that the massage treatment is effective in improving postoperative pain and ankle function.

Keywords: massage therapy, soft tissue release, deep tissue massage, ankle injury

\section{PENDAHULUAN}

Dislokasi sendi dapat memungkinkan terjadinya pergeseran atau keluarnya ligamen dari jalurnya sehingga rasa nyeri yang dirasakan tak kunjung hilang dan ligamen rentan mengalami robekan yang lebih parah. Cedera pada sendi ankle tidak bisa dianggap remeh karena berdasarkan observasi peneliti di lingkungan sekitar cedera sendi ankle merupakan salah satu kasus cedera yang sering terjadi di kehidupan sehari-hari khususnya di lingkup orang-orang yang banyak beraktivitas dengan bagian tubuh ekstremitas bawah dan orang-orang yang menghabiskan banyak waktu untuk berjalan atau berlari. Sebagian orang mengabaikan cedera ini dan membiarkan membaik dengan sendirinya ini merupakan dampak kurangnya pemahaman tentang cedera sendi ankle dan penanganannya, padahal kondisi kaki yang cedera akan mengganggu aktivitas lainnya sehari-hari. Pembiaran pada cedera juga meningkatkan risiko terjadinya cedera yang sama dapat berulang dikemudian hari.

Olahraga merupakan salah satu contoh aktivitas dengan tingkat risiko terjadinya sprain ankle yang tinggi, umumya pada olahraga yang mengandalkan agility atau kelincahan yang mengharuskan seseorang untuk menendang, melompat, berlari sekaligus merubah arah dalam kecepatan tinggi. Abdurrahman (2015: 30) mengungkapkan pada pelaksanaan Pra PON 2015 cabor taekwondo, terdapat 37 atlet yang mengalami cedera, 3 kasus terbanyak adalah cedera lutut (knee sprain) sebanyak 10 kasus (27\%), cedera ankle (ankle sprain) sebanyak 7 kasus $(18 \%)$ dan cedera hamstring sebanyak 4 kasus (10\%). Data lain menyebutkan diagnosa cedera tertinggi dalam tiga kali pelaksanaan piala dunia futsal berturut-turut $(2000,2004$, dan 2008) berupa memar di area tungkai bawah (11\%), sprain ankle (10\%), strain groin (8\%) (Junge \& Dvorak, 2010: 1090). Dari data diatas cedera sprain ankle menjadi salah satu cedera yang cukup sering terjadi dalam suatu pertandingan atau event olahraga.

Semakin berkembangnya ilmu pengetahuan, semakin banyak cara yang dapat dilakukan dalam penanganan cedera, namun efektivitas yang dihasilkan masih bervariasi. Variasi ini dipengaruhi oleh banyak faktor seperti jenis cedera yang ditangani, kondisi pasien, dan lainlain. Salah satu pengobatan yang berkembang belakangan ini adalah terapi masase. Terapi masase adalah manual terapi yang digunakan dalam membantu seseorang yang mengalami kelelahan, cedera ataupun sekedar perawatan tubuh dengan cara sentuhan tangan pada permukaan kulit guna mengurangi ketegangan otot, memposisikan persendian dan memperlancar peredaran darah sehingga tubuh terasa bugar, nyaman, serta dapat mengurangi proses peradangan seperti panas, merah, nyeri, bengkak dan keterbatasan sendi (Graha \& Priyonoadi, 2012: 1). Terapi masase merupakan terapi manual yang murah, sederhana, dan cenderung aman dari segi efek samping, sebagian orang juga meyakini bahwa masase memiliki efektivitas yang tinggi untuk penanganan beberapa jenis cedera sehingga dengan risiko yang rendah dan informasi positif yang berkembang di masyarakat, masase dapat diterima di masyarakat luas dan banyak dipilih sebagai pengobatan alternatif maupun pengobatan utama suatu cedera.

\section{METODE}

Penelitian ini menggunakan metode pre-experimental design dengan model one-group pre-test - post-test design, dimana subjek penelitian menjadi satu kelompok kemudian dilakukan pendataan dan pengukuran sebelum dan setelah diberikan treatment dengan maksud dapat diketahui ada tidaknya perubahan yang dialami subjek sebelum dan setelah diberikan 
treatment. Penelitian ini menggunakan populasi pasien Laboratorium Terapi Latihan FIK UNY yang selama tiga bulan (Februari - April 2019) diperkirakan sejumlah 100 orang.

Instrumen yang digunakan dalam penelitian ini berupa catatan medis hasil dari anamnesa dan pemeriksaan yang dibuat dengan memodifikasi Lower Extremity Functional Scale (Binkley et al, 1999). Data yang ingin diperoleh dari anamnesa yaitu aktivitas fisik sehari-hari, tinggi badan, berat badan, riwayat cedera ankle, durasi cedera, dan penyebab cedera. Aktivitas fisik dibedakan menjadi 3 kelompok yaitu subjek dengan aktivitas fisik ringan dimana dalam seharihari ia hanya melakukan pekerjaan/aktivitas yang ringan tidak memerlukan banyak tenaga dan tidak sampai mengakibatkan kelelahan fisik, kemudian sedang dimana dalam sehari-hari subjek melakukan pekerjaan yang cukup melelahkan atau pekerjaan yang ringan tetapi ditambah aktivitas di luar pekerjaan yang cukup melelahkan namun dengan jeda istirahat yang masih cukup panjang, dan berat dimana dalam sehari-hari subjek melakukan pekerjaan/aktivitas yang melelahkan dengan jeda istirahat cenderung singkat.

\section{Teknik analisis data}

Data penelitian berupa data demografi meliputi umur, pekerjaan, aktivitas fisik, berat badan, tinggi badan dan indeks massa tubuh yang akan dianalisis secara deskriptif kuantitatif.

Data cedera ankle meliputi riwayat cedera, durasi cedera, dan penyebab cedera juga akan dianalisis secara deskriptif kuantitatif. Data tentang nyeri gerak dan fungsi gerak sendi ankle sebelum dan sesudah perlakuan dianalisis dengan menggunakan uji beda dua kelompok berpasangan non-parametrik yaitu Wilcoxon Signed Ranks Test.

\section{HASIL DAN PEMBAHASAN}

Penelitiaan ini bertujuan mengetahui efektivitas terapi masase yang meliputi pelemasan otot dengan soft tissue release dan deep tissue massage yang disertai reposisi gerak terhadap cedera ankle, dalam penelitian ini terekrut subjek mayoritas remaja dan dewasa karena rentang usia subjek penelitian dipengaruhi oleh cara peneliti menyebarkan informasi terkait penelitian ini, dimana peneliti menggunakan perantara media sosial whatsapp sehingga kalangan yang menerima informasi ini merupakan pengguna aktif smartphone yang notabene berusia remaja hingga dewasa. Pekerjaan subjek penelitian didominasi oleh mahasiswa/pelajar karena dipengaruhi faktor jaringan peneliti dan juga cara penyebaran informasi terkait penelitian ini. Tidak hanya mahasiswa FIK UNY terdapat juga subjek penelitian dari fakultas dan universitas lain, berdasarkan observasi dan wawancara dengan subjek diperoleh informasi bahwa seluruh subjek baik mahasiswa atau pelajar memiliki hobi berolahraga maupun aktivitas fisik lainnya sehingga rentan mengalami cedera. Kemudian 3 dari 4 subjek yang bekerja sebagai wiraswasta juga menggemari olahraga.

Setiawan (2011: 95) berpendapat salah satu penyebab cedera olahraga adalah faktor dari dalam yaitu berupa anatomi, latihan gerakan/pukulan yang keliru, adanya kelemahan otot, dan tingkat kebugaran rendah, berdasarkan data penelitian ini kasus cedera banyak terjadi pada subjek dengan aktivitas fisik ringan dan sedang, bisa dikatakan cedera yang terjadi dipengaruhi oleh faktor kebugaran jasmani subjek. Sulistiono (2014: 381-382) berpendapat kebugaran jasmani (physical fitness) adalah kondisi fisik yang memungkinkan seseorang melakukan kegiatan rutin tanpa mengalami kelelahan yang berarti dan bila perlu masih dapat melakukan kegiatan tambahan serta masih dapat menikmati waktu luangnya. Seseorang yang memiliki tingkat kebugaran jasmani yang tinggi dapat melakukan aktivitas fisik seperti belajar, bekerja atau berolahraga dengan baik tanpa merasa terlalu lelah. Seseorang dengan aktivitas fisik yang ringan dan sedang cenderung memiliki kebugaran jasmani yang rendah dan standar sehingga rentan mengalami cedera ketika melakukan aktivitas yang berat seperti berolahraga dengan tempo cepat dan dalam durasi yang lama. Begitupula sebaliknya seseorang dengan aktivitas fisik berat sehari-hari akan lebih siap menerima beban yang dapat mengakibtkan cedera karena kebugaran jasmani yang lebih baik, namun terdapat beberapa faktor yang dapat mengakibatkan 
seseorang dengan aktivitas fisik berat mengalami cedera salah satunya overuse ini dikarenakan kurangnya waktu istirahat atau beban latihan yang terlalu dipaksakan. Ihsan (2017: 69) menyatakan sendi ankle menjadi salah satu sendi yang paling besar persentase cederanya karena sebagai penggerak dan penahan berat badan, sehingga kemungkinan cedera tinggi. Bisa dikatakan bahwa berat badan merupakan faktor yang dapat meningkatkan kemungkinan terjadinya cedera, maka semakin tinggi indeks massa tubuh seseorang akan meningkatkan risiko terjadinya cedera sendi ankle. Namun sebagian besar cedera yang terjadi pada penelitian ini tidak dipengaruhi oleh indeks massa tubuh melainkan terdapat penyebab lain, bisa dilihat dari data yang diperoleh sebagian besar subjek memiliki indeks massa tubuh normal, kecuali beberapa subjek yang termasuk dalam kategori gemuk (berlebihan berat badan tingkat ringan) dan gemuk (berlebihan berat badan tingkat berat) terdapat kemungkinan cedera yang dialami dipengaruhi oleh indeks massa tubuh yang berlebih.

Hasil keseluruhan analisis data penelitian menunjukan bahwa terapi masase yang meliputi pelemasan otot dengan soft tissue release dan deep tissue massage yang disertai reposisi gerak efektif terhadap penurunan nyeri gerak dan peningkatan fungsi gerak sendi ankle pasca cedera sendi ankle pasien Laboratorium Terapi Latihan FIK Universitas Negeri Yogyakarta. Melalui hasil uji Wilcoxon Signed Ranks Test diketahui bahwa terdapat penurunan skala nyeri gerak dan peningkatan fungsi gerak sendi ankle yang signifikan.

Cedera ankle merupakan salah satu cedera yang kerap dialami seseorang baik dalam aktivitas sehari-hari maupun saat berolahraga, umumnya cedera terjadi ketika seseorang terjatuh dengan tumpuan kaki yang salah, benturan fisik di area ankle/pergelangan kaki atau karena overuse syndrome (sindrom pemakaian berlebih). Cedera mengakibatkan nyeri gerak dan penurunan fungsi gerak sendi ankle, ini merupakan akibat dari robekan ligamen baik secara mikroskopis atau lebih parah dan bisa disertai pergeseran atau keluarnya ligamen dari jalurnya sehingga rasa nyeri yang dirasakan tak kunjung hilang dan ligamen rentan mengalami robekan yang lebih parah juga dapat mengakibatkan kendurnya ligamen sendi sehingga cedera mudah terulang. Cedera pada sendi ankle juga dapat mengakibatkan ketegangan pada otot penopang sendi ankle ini bisa terjadi akibat dari pola jalan yang tidak normal yang akhirnya membebani otot yang bekerja dalam gerakan berjalan atau berlari. Dampaknya cedera pada sendi ankle akan mengakibatkan kondisi ketidak mampuan sendi dalam menopang aktivitas serta menahan beban tubuh, Arovah (2010: 3) menyatakan kelemahan fungsi berupa penurunan kekuatan dan keterbatasan jangkauan gerak sering dijumpai pada kasus cedera.

Terapi masase yang meliputi pelemasan otot dengan soft tissue release melalui manipulasi gerakannya memberikan efek relaks pada jaringan lunak di sekitar area cedera terutama otot penopang sendi ankle, melalui gerakan penekanan dan stretching/peregangan yang menyeluruh di area permukaan otot-otot tungkai bawah menghilangkan kekakuan otot yang terjadi akibat dari cedera, jadi selain manipulasi manual therapy pada soft tissue release juga terdapat manipulasi exercise therapy yaitu berupa gerakan stretching/peregangan. Kisner dan Colby (2007: 66) menyatakan, latihan peregangan dianggap sebagai elemen penting dalam kebugaran dan program pengondisian yang dirancang untuk mempromosikan kesehatan dan mengurangi resiko cedera dan cedera berulang. Begitupula dengan deep tissue massage melalui manipulasi gerakan yang diberikan yaitu gerakan stroke/penekanan yang dalam dan perlahan menggunakan siku dan lengan bawah terapis di area permukaan otot-otot tungkai bawah memberikan efek relaks dan nyaman pada pasien yang dapat memicu hormon endorphin yang mampu mengurangi rasa nyeri. Secara tidak langsung pelemasan otot dengan soft tissue release atau deep tissue massage yang menghilangkan kekakuan otot dan memberikan kenyamanan pada otot dan jaringan lunak lainnya membantu meningkatkan fungsi gerak sendi ankle karena pada setiap gerakan sendi memerlukan bantuan daripada jaringan lunak dan otot-otot penopang di sekitar sendi. Kemudian penanganan reposisi gerak yang diberikan dengan gerakan peregangan pasif dan PNF pada sendi ankle memberikan efek penurunan nyeri gerak melalui 
gerakan-gerakan mobilisasi sendi dan juga peningkatan fungsi gerak melalui peningkatan ROM pada sendi ankle, ini bisa dilihat melalui hasil analisis data terdapat penurunan skala nyeri gerak pada semua subjek penelitian dan peningkatan skala fungsi gerak pada 19 subjek penelitian dengan 1 sisanya tidak mengalami perubahan baik peningkatan maupun penurunan fungsi gerak sendi. Tingkat efektivitas yang dihasilkan dari penanganan terapi yang diberikan lebih optimal pada pengurangan nyeri gerak sendi ankle $(70,31 \%)$ sedangkan pada peningkatan fungsi gerak sendi ankle kurang begitu optimal (20,62\%) ini dikarenakan untuk peningkatan fungsi gerak dibutuhkan lebih dari penanganan terapi pasif, diperlukan terapi aktif yaitu terapi latihan yang melibatkan latihan penguatan dan daya tahan otot-otot dan jaringan lunak pada bagian kaki cedera sehingga peningkatan fungsi gerak sendi ankle akan lebih optimal, jadi penulis menyarankan untuk menyertai program terapi latihan pasca terapi masase.

Lokasi yang digunakan dalam melaksanakan penelitian ini adalah Klinik Olahraga Terapi dan Rehabilitasi FIK UNY yang dalam hal ini dilakukan di Poliklinik UNY. Subjek dalam penelitian ini merupakan pasien Klinik Olahraga Terapi dan Rehabilitasi FIK UNY selama bulan Oktober-Desember 2017 yang mengalami nyeri dan ketegangan otot leher sampai menggangu fungsi gerak leher.

Subjek dalam penelitian ini berjumlah 15 orang dengan rincian 10 orang laki-laki, dan 5 orang perempuan, sehingga didapatkan persentase pasien laki-laki sebesar 66,7\%, dan pasien perempuan sebesar 33,3\%. Rentang usia dari subjek penelitian ini berkisar pada 19-24 tahun, dengan rata-rata berusia 21,7 tahun dan standar deviasi 2,5. Rata-rata pekerjaan yang dimiliki subjek penelitian yaitu sebagai mahasiswa berumlah 13 dengan persentase $86,7 \%$. Sembilan dari 13 mahasiswa sebagai subjek penelitian memiliki profesi sebagai olahragawan yaitu berjumlah 9 orang. Berat badan dari subjek penelitian ini berkisar antara 45-75,5 kg, dengan rata-rata berbobot $62,57 \mathrm{~kg}$ dan standar deviasi 8,94. Tinggi badan dari subjek penelitian adalah $151-180 \mathrm{~cm}$ dengan rata-rata $165,23 \mathrm{~cm}$ dan standar deviasi 8,70 . Pengukuran yang dilakukan terhadap 15 subjek dalam penelitian ini meliputi ROM, skala nyeri, dan skala fungsi.

\section{Deskripsi data penelitian}

Data yang didapatkan dalam penelitian ini berdasarkan anamnesa, dan pemeriksaan sebelum dan setelah perlakuan. Data tersebut dianalisis secara deskriptif dengan tujuan untuk mempermudah penyajian data penelitian. Hasil analisis deskriptif pada masing-masing data penelitian adalah sebagai berikut:

\section{Riwayat cedera ankle}

Berdasarkan data 14 dari 20 subjek penelitian memiliki riwayat cedera ankle dan 6 sisanya merupakan cedera pertama kali. Rentang riwayat cedera ankle subjek penelitian ini adalah 6-132 bulan atau setengah tahun sampai 11 tahun dengan rata-rata 53,57 bulan atau sekitar 4,4 tahun dan standar deviasi 37,541.

\section{Durasi cedera ankle}

Rentang durasi cedera subjek penelitian ini adalah 1-93 hari dengan rata-rata 27,90 hari dan standar deviasi 31,795. Kisner dan Colby (2007: 297) berpendapat tahap cedera akut biasanya berlangsung $4-6$ hari sejak cedera dialami, sedangkan tahap sub akut dapat berlangsung $10-17$ hari atau $4-21$ hari sejak terjadinya cedera, dan tahap kronis dapat berlangsung $6-12$ bulan atau 21 hari - 12 bulan tergantung pada jaringan yang terlibat dan jumlah kerusakan jaringan. Berdasarkan data diatas diketahui subjek dengan durasi cedera kurang dari 30 hari merupakan kelompok terbanyak dengan jumlah 13 orang, secara durasi terdapat 4 subjek yang termasuk ke dalam fase cedera akut namun secara kondisi tidak ada indikasi gejala cedera akut karena ke 4 subjek memiliki riwayat cedera sendi ankle, jadi bisa dikatakan ke 4 subjek termasuk ke dalam fase kronik. 


\section{Penyebab cedera ankle}

Berdasarkan anamnesa 19 dari 20 cedera subjek terjadi ketika sedang berolahraga dan 1 sisanya merupakan akibat dari kecelakaan berkendara. terdapat 3 penyebab cedera ankle pada subjek penelitian ini dengan jumlah tertinggi yaitu jatuh/terkilir sebanyak 10 orang atau 50\%, kemudian kontak fisik atau benturan pada ankle sebanyak 8 orang atau 40\%, dan yang paling sedikit yaitu overuse sebanyak 2 orang atau $10 \%$.

\section{Nyeri gerak}

Hasil anamnesa dan pemeriksaan nyeri gerak melalui instrumen catatan medis yang telah dirancang. Rentang skala nyeri gerak pre-test yang dialami oleh subjek adalah 12,5-50\% dengan rata-rata nyeri gerak 26,245\% dan standar deviasi 12,6014. Sedangkan rentang skala nyeri gerak post-test yang dialami oleh subjek adalah $0-25 \%$ dengan rata-rata nyeri gerak $7,790 \%$ dan standar deviasi 8,8027 . Nilai normal $\mathrm{Z}$ terstandarisasi dari data nyeri gerak posttest - nyeri gerak pre-test adalah -3,938 (berdasarkan peringkat positif), jika level signifikansi yang digunakan adalah 0,05 maka nilai probabilitas kumulatif dari $-3,938$ adalah 0,000 (Asymp. Sig. 2-tailed) dan jika merupakan uji satu sisi, nilai probabilitas dibagi dua $(0,000<$ 0,05) maka H0 ditolak dan $\mathrm{H} 1$ diterima. Berdasarkan data seluruh subjek mengalami penurunan tingkat skala nyeri gerak dan melalui uji signifikansi hipotesis diterima, maka dapat dinyatakan bahwa terjadi perubahan yang signifikan antara skala data subjek pre-test dan post-test atau dapat ditarik kesimpulan bahwa terapi masase dapat menurunkan nyeri gerak secara signifikan pada subjek cedera sendi ankle. Melalui uji efektivitas diperoleh nilai persentase efektivitas penurunan skala nyeri gerak sendi ankle pada penelitian ini adalah 70,32\%.

\section{Fungsi ankle}

Hasil anamnesa dan pemeriksaan fungsi gerak melalui instrumen catatan medis yang telah dirancang. Rentang skala fungsi ankle pre-test yang dicapai oleh subjek adalah 35,7$92,8 \%$ dengan rata-rata fungsi ankle 76,215\% dan standar deviasi 13,1632. Sedangkan rentang skala fungsi ankle post-test yang dicapai oleh subjek adalah 71,4-100\% dengan rata-rata fungsi ankle $91,930 \%$ dan standar deviasi 6,9430. Nilai normal Z terstandarisasi dari data fungsi gerak post-test - fungsi gerak pre-test adalah -3,830 (berdasarkan peringkat negatif), jika level signifikansi yang digunakan adalah 0,05 maka nilai probabilitas kumulatif dari $-3,830$ adalah 0,000 (Asymp. Sig. 2-tailed) dan jika merupakan uji satu sisi, nilai probabilitas dibagi dua $(0,000<0,05)$ maka H0 ditolak dan $\mathrm{H} 1$ diterima.

Berdasarkan data 19 dari 20 subjek mengalami peningkatan skala fungsi ankle dan 1 sisanya tidak mengalami penurunan maupun peningkatan skala fungsi ankle dan melalui uji signifikansi hipotesis diterima, maka dapat dinyatakan bahwa terjadi perubahan yang signifikan antara skala data subjek pre-test dan post-test atau dapat ditarik kesimpulan bahwa terapi masase dapat meningkatkan fungsi gerak secara signifikan pada subjek cedera sendi ankle. Melalui uji efektivitas diperoleh nilai persentase efektivitas peningkatan skala fungsi gerak sendi ankle pada penelitian ini adalah 20,62\%.

\section{Hasil analisis data penelitian}

Terapi masase yang meliputi pelemasan otot dengan soft tissue release melalui manipulasi gerakannya memberikan efek relaks pada jaringan lunak di sekitar area cedera terutama otot penopang sendi ankle, melalui gerakan penekanan dan stretching/peregangan yang menyeluruh di area permukaan otot-otot tungkai bawah menghilangkan kekakuan otot yang terjadi akibat dari cedera, jadi selain manipulasi manual therapy pada soft tissue release juga terdapat manipulasi exercise therapy yaitu berupa gerakan stretching/peregangan. Kisner dan Colby (2007: 66) menyatakan, latihan peregangan dianggap sebagai elemen penting dalam kebugaran dan program pengondisian yang dirancang untuk mempromosikan kesehatan dan mengurangi resiko cedera dan cedera berulang. Begitupula dengan deep tissue massage melalui 
manipulasi gerakan yang diberikan yaitu gerakan stroke/penekanan yang dalam dan perlahan menggunakan siku dan lengan bawah terapis di area permukaan otot-otot tungkai bawah memberikan efek relaks dan nyaman pada pasien yang dapat memicu hormon endorphin yang mampu mengurangi rasa nyeri.

Secara tidak langsung pelemasan otot dengan soft tissue release atau deep tissue massage yang menghilangkan kekakuan otot dan memberikan kenyamanan pada otot dan jaringan lunak lainnya membantu meningkatkan fungsi gerak sendi ankle karena pada setiap gerakan sendi memerlukan bantuan daripada jaringan lunak dan otot-otot penopang di sekitar sendi. Kemudian penanganan reposisi gerak yang diberikan dengan gerakan peregangan pasif dan PNF pada sendi ankle memberikan efek penurunan nyeri gerak melalui gerakan-gerakan mobilisasi sendi dan juga peningkatan fungsi gerak melalui peningkatan ROM pada sendi ankle, ini bisa dilihat melalui hasil analisis data terdapat penurunan skala nyeri gerak pada semua subjek penelitian dan peningkatan skala fungsi gerak pada 19 subjek penelitian dengan 1 sisanya tidak mengalami perubahan baik peningkatan maupun penurunan fungsi gerak sendi. Tingkat efektivitas yang dihasilkan dari penanganan terapi yang diberikan lebih optimal pada pengurangan nyeri gerak sendi ankle $(70,31 \%)$ sedangkan pada peningkatan fungsi gerak sendi ankle kurang begitu optimal $(20,62 \%)$ ini dikarenakan untuk peningkatan fungsi gerak dibutuhkan lebih dari penanganan terapi pasif, diperlukan terapi aktif yaitu terapi latihan yang melibatkan latihan penguatan dan daya tahan otot-otot dan jaringan lunak pada bagian kaki cedera sehingga peningkatan fungsi gerak sendi ankle akan lebih optimal, jadi penulis menyarankan untuk menyertai program terapi latihan pasca terapi masase.

\section{Pembahasan hasil penelitian}

Hasil keseluruhan analisis data penelitian menunjukan bahwa terapi masase yang meliputi pelemasan otot dengan soft tissue release dan deep tissue massage yang disertai reposisi gerak efektif terhadap penurunan nyeri gerak dan peningkatan fungsi gerak sendi ankle pasca cedera sendi ankle pasien Laboratorium Terapi Latihan FIK Universitas Negeri Yogyakarta. Melalui hasil uji Wilcoxon Signed Ranks Test diketahui bahwa terdapat penurunan skala nyeri gerak dan peningkatan fungsi gerak sendi ankle yang signifikan.

Cedera ankle merupakan salah satu cedera yang kerap dialami seseorang baik dalam aktivitas sehari-hari maupun saat berolahraga, umumnya cedera terjadi ketika seseorang terjatuh dengan tumpuan kaki yang salah, benturan fisik di area ankle/pergelangan kaki atau karena overuse syndrome (sindrom pemaikaian berlebih). Cedera mengakibatkan nyeri gerak dan penurunan fungsi gerak sendi ankle, ini merupakan akibat dari robekan ligamen baik secara mikroskopis atau lebih parah dan bisa disertai pergeseran atau keluarnya ligamen dari jalurnya sehingga rasa nyeri yang dirasakan tak kunjung hilang dan ligamen rentan mengalami robekan yang lebih parah juga dapat mengakibatkan kendurnya ligamen sendi sehingga cedera mudah terulang. Cedera pada sendi ankle juga dapat mengakibatkan ketegangan pada otot penopang sendi ankle ini bisa terjadi akibat dari pola jalan yang tidak normal yang akhirnya membebani otot yang bekerja dalam gerakan berjalan atau berlari. Dampaknya cedera pada sendi ankle akan mengakibatkan kondisi ketidak mampuan sendi dalam menopang aktivitas serta menahan beban tubuh, Arovah (2010: 3) menyatakan kelemahan fungsi berupa penurunan kekuatan dan keterbatasan jangkauan gerak sering dijumpai pada kasus cedera.

Hasil keseluruhan analisis data penelitian menunjukan bahwa terapi masase yang meliputi pelemasan otot dengan soft tissue release dan deep tissue massage yang disertai reposisi gerak efektif terhadap penurunan nyeri gerak dan peningkatan fungsi gerak sendi ankle pasca cedera sendi ankle pasien Laboratorium Terapi Latihan FIK Universitas Negeri Yogyakarta. Melalui hasil uji Wilcoxon Signed Ranks Test diketahui bahwa terdapat penurunan skala nyeri gerak dan peningkatan fungsi gerak sendi ankle yang signifikan. 


\section{SIMPULAN}

Secara keseluruhan dapat ditarik kesimpulan bahwa terapi masase yang meliputi pelemasan otot dengan soft tissue release atau deep tissue massage dan ditambah dengan reposisi gerak dapat mengurangi nyeri gerak dan meningkatkan fungsi gerak dari sendi ankle pasca cedera ankle, dengan efektivitas penurunan nyeri gerak sebesar $70,31 \%$ dan peningkatan fungsi gerak sebesar $20,62 \%$.

\section{DAFTAR PUSTAKA}

Arovah, N. I. (2009). Diagnosis dan Manajemen Cedera Olahraga. Yogyakarta: FIK UNY.

Arovah, N. I. (2010). Dasar-Dasar Fisioterapi pada Cedera Olahraga. Yogyakarta: FIK UNY.

Binkley et al. (1999). The Lower Extremity Functional Scale (LEFS): Scale development, mearsurement properties, and clinical application. Physical Therapy. 79: 371-383.

Graha, A. S. \& Priyonoadi, B. (2012). Terapi Masase Frirage Penatalaksanaan Cedera Pada Anggota Gerak Tubuh Bagian Bawah. Yogyakarta: FIK UNY.

Graha, A. S. (2013). Masase Terapi Cedera Olahraga Metode Ali Satia Graha (Therapy Massage Sport Injury). Daerah Istimewa Yogyakarta.

Ihsan, M. (2017). Survey Cedera Olahraga pada Atlet Cabang Olahraga Bola Basket di Club XYZ Junior Medan Labuhan. Jurnal Ilmu Keolahragaan Vol. 16 (1), Hlm 62-72.

Junge, A. \& Dvorak, J. (2014). Injury Risk of Playing Football in Futsal World Cups Journal. Switzerland: Br J Sport Med, 1089-1092.

Kisner, C. \& Colby, L. A. (2007). Therapeutic Exercise (5th ed.). United States of America: F. A. Davis Company Inc. Klonisch, T. \& Hombach-Klonisch, S. (2011). Sobotta Atlas of Human Anatomy. Elsevier GmbH, Munich.

Meliala, L. (2004). Nyeri Keluhan yang Terabaikan: Konsep Dahulu, Sekarang, dan yang akan Datang, Pidato Pengukuhan Jabatan Guru Besar, Fakultas Kedokteran Universitas Gadjah Mada.

Setiawan, A. (2011). Faktor Timbulnya Cedera Olahraga. Jurnal Media Ilmu Keolahragaan Indonesia. Vol 1, 94-98.

Sulistiono, A. A. (2014). Prediksi Aktivitas Fisik Sehari-hari, Umur, Tinggi, Berat Badan dan Jenis Kelamin terhadap Kebugaran Jasmani Siswa SMP di Banjarmasin. Puslitjak, Balitbang-Kemdikbud. Hlm 380-389.Admadja, A.S. (2016). Sindrom Nyeri Myofascial. Continuing Medical Education, 43 (3), 176-179. 